13.8 $\mathrm{mm}$. Hg. They point out, however, that this varies with limb circumferences. Tailor-made elastic stockings are probably excellent for outpatient management, though we have not investigated as yet the pressure they exert. Inpatient management would seem to indicate the use of inflatable splints.

We wish to thank Mr. L. T. Cotton (King's College Hospital) and Professor J. M. Zarek (University of Surrey), joint heads of the biomechanics department of King's College Hospital Medical School, for their guidance and advice throughout the preparation of this paper. We also thank the sister tutors and nurses of the Training School at King's College Hospital for their kind cooperation in the leg-bandaging investigation, and Parke Davis \& Co. for supplying the inflatable splints.

The work was financed by grants from the Wates Foundation and the British Heart Foundation, to whom we express our thanks.
REFERENCES

Ashton, H. (1966). British Medical fournal, 2, 1427.
Beaconsfield, P., and Ginsburg, J. (1955). Circulation Research, 3, 478.

Campion, E. C., Hoffman, D. C., and Jepson, R. P. (1968). Australian and New Zealand fournal of Surgery, 38, 154 .

Cotton, L. T., and Clark, C. (1965). Annals of the Royal College of Surgeons of England, 36, 214

Dyde, J. A., and Bethel, A. N. (1968). British fournal of Surgery, 55, Flanc, C., Kakkar, V. V., and Clarke, M. B. (1969). Lancet, 1, 477.

Ginsberg, M., Miller, J.' M., and McElfatrick, G. C. (1967). Fournal of the American Medical Association, 200, 180.

Hodgson, D. C. (1964). Anaesthesia, 19, 96.

Husni, E. A., Ximenes, J. O. C., and Hamilton, F. G. (1968). fournal of the American Medical Association, 206, 2715.

McLachlin, A. D., McLachlin, J. A., Jory, T. A., and Rawling, E. G. (1960). Annals of Surgery, 152, 678.

McLachlin, J., and Paterson, J. G. (1951). Surgery, Gynecology and Obstetrics, 93, 1.

Makin, G. S., Mayes, F. B., and Holroyd, A. M. (1969). British fournal of Surgery, 56, 369.

Stanton, J. R., Freis, E. D., and Wilkins, R. W. (1949). Fournal of
Clinical Investigation, 28, 553. Wright, H. P., and Osborn, S. B. (1952). British Heart fournal, 14, 325.

\title{
Intravenous Isoprenaline in Treatment of Septic Shock in Man
}

\author{
J. L. WOSORNU, ${ }^{*}$ F.R.c.s. ; C. O. EASMON, $†$ F.R.c.S., F.I.c.s.
}

\begin{abstract}
Cummary: Intravenous isoprenaline was given to 10 patients in septic shock, of which occult myocardial failure was the main indication. Isoprenaline expedited recovery in cases of "benign hypotension," where kidney function paradoxically remained satisfactory at low systolic pressures, and was useful in cases of "cold hypotension" which were complicated by renal failure alone. No significant improvement occurred in cases which were complicated by both massive pulmonary oedema and acute renal failure.
\end{abstract}

\section{Introduction}

Most patients in septic shock can be managed successfully with the appropriate antibiotics in large doses, intravenous fluids, the use of oxygen, and timely surgery where applicable-in particular, drainage of closed foci of infection (Nickerson, 1962; Walters and McGowan, 1963; Frank, 1964; Lillehei et al., 1964; Baue, 1968; Blair et al., 1969). Vasodilator drugs, however, are recommended in patients who do not respond to adequate transfusion (Lancet, 1965). Examples of such drugs are hydrocortisone in massive doses, phenoxybenzamine, isoprenaline, chlorpromazine, and phentolamine.

The indications, dose, response, and side-effects of adjuvant intravenous isoprenaline in the treatment of septic shock are described. Prognosis is considered in relation to the severity of the shock syndrome. Isoprenaline was found useful in patients in whom hypotension was associated with small pulse volume and warm or cold extremities. On the other hand, with the limited resources available, it did not appreciably improve the outlook for patients who had both pulmonary oedema and acute renal failure.

\footnotetext{
* Lecturer in Surgery, Ghana Medical School, Accra, Ghana. Present address: Department of Surgery, Royal Postgraduate Medical School, Hammersmith Hospital, London W.12.

+ Professor and Head of Department of Surgery, Ghana Medical School, Accra, Ghana.
}

\section{Patients and Methods}

A prospective study was carried out on 12 patients in the Korle Bu Teaching Hospital, Accra, Ghana, who were in septic shock and in whom conventional antishock therapy had failed. Of these, 10 were women and 2 men, their ages ranging from 16 to 60 years.

All patients had severe bacterial infection associated with the following features: low blood pressure, which in five cases was unrecordable, while in the remainder the systolic was 90 $\mathrm{mm} . \mathrm{Hg}$ or lower; radial pulse rates of between 110 and 172 beats/min., which was of small volume in nine cases, imperceptible in one, but collapsing in character in two; cutaneous vasoconstriction associated with sweating (cold, clammy extremities), which was present in half the cases while extremities were warm and dry in the rest. All patients were pyrexial, with rectal temperatures ranging between 100 and $108^{\circ} \mathrm{F}$. $(37.8$ and $42.2^{\circ} \mathrm{C}$.) (though patients in septic shock may have subnormal temperatures). Oliguria (urine output below 20 $\mathrm{ml}$./hr.) was present in half the cases, including three with acute renal failure.

Thus according to the clinical classification proposed by McGowan and Walters (1966) there were six patients with "cold hypotension," one with "warm hypotension," four in whom hypotension was associated with warm extremities but small pulse volume, and one with hypotension, cold extremities, but good pulse volume.

Central venous pressure, urinary output, and electrocardiogram were monitored as well as pulse, blood pressure, temperature, and respiration. (Cardiac output, $p \mathrm{H}, \mathrm{PcO}_{2}$, and $\mathrm{Po}_{2}$ could not be measured because of lack of facilities.)

Blood pressure was measured by means of a sphygmomanometer (Kardos, 1966). Furthermore, the comment that "blood pressure is, in our experience, still best measured by the mercury sphygmomanometer at the bedside and only in special cases via an indwelling arterial cannula" (Campbell et al., $1967)$ is relevant to this clinical study. Mean arterial pressure was calculated as an approximation by adding diastolic pressure to one-third pulse pressure. 
Central venous pressure was measured with a spinal water manometer. The median basilic vein was exposed and cannulated with a No. 7 cardiac catheter. Entry of the catheter into the great veins was indicated by free oscillations of the water meniscus with breathing. Zero point was taken as $5 \mathrm{~cm}$. posterior to the angle of Louis with the patient flat and in the supine position (MacLean, 1966). Urinary output was measured hourly by means of an indwelling urethral catheter.

All patients received adequate transfusion and large doses of antibiotics. Foci of infection were drained surgically in all except Cases 3 and 7, who were too ill for operation. Patients were cooled frequently by tepid sponging. Other measures were taken as indicated and tracheostomy was performed in one case. Digitalis was not used routinely.

At the beginning of the study intravenous penicillin 20 million to 50 million units and intramuscular chloramphenicol 2-4 g. daily in divided doses were used together. The last five patients (Cases 8-12) received cephaloridine (Ceporin) in a dose of 2-4 g. daily, depending on renal function.

Isoprenaline (Suscardin) was obtained in 200- $\mu \mathrm{g}$. ampoules. Pharmacologically, isoprenaline stimulates the $\beta$-adrenergic receptors. Thus it produces an increased heart rate and stroke volume and reduces peripheral resistance. The combined effect of the cardiac and peripheral actions in man is a pronounced increase in cardiac output, a variable effect on systolic pressure, and a fall in diastolic pressure (Innes and Nickerson, 1960), which in turn improves tissue perfusion.

Indications.-Isoprenaline was not used routinely in this series. For example both Cases 5 and 12 were treated successfully with antibiotics and intravenous fluids. But isoprenaline was used in cases of "occult myocardial failure" (Siegel and Fabian, 1967) when raised central venous pressure $(>120$ $\mathrm{mm} . \mathrm{H}_{2} \mathrm{O}$ ) failed to raise arterial blood pressure, increase volume of radial pulse, improve flow of urine, and abolish cutaneous vasoconstriction. Du Toit et al. (1966) and MacLean (1966) used similar criteria.

A recommended dose of isoprenaline in septic shock is $\mathbf{0 . 2}$ to $0.4 \mu \mathrm{g} . / \mathrm{min}$., which is obtained by diluting $200 \mu \mathrm{g}$. in 500 $\mathrm{ml}$. of normal saline and giving this solution at the rate of 10-20 drops/min. (Baue, 1968).

\section{Results}

Eight patients survived the shock episode, but one (Case 11) died 18 hours after massive resection of gangrenous small intestine, giving an overall acute mortality of $41.7 \%$.

The 10 patients who received isoprenaline in this series may be grouped as follows (see Table). Two had hypotension with small pulse volume and warm extremities without oliguria (Cases 1 and 2); three had hypotension with small pulse volume and cold extremities without oliguria (Cases 3, 4, and 6); and four had "cold hypotension" with oliguria (Cases 7, 8, 10, and 11). Case 9 was an exception; she had hypotension with warm extremities and "bounding" radial pulse, but she was also oliguric. This classification was of prognostic value.

\section{Case 2}

A 34-year-old woman was admitted urgently with obstructed labour and intrauterine death at term. She was delivered of a macerated fetus with minimal blood loss. The liquor was offensive and bubbly. Crepitus was felt in the uterus on abdominal palpation. Six hours after delivery she collapsed suddenly with an unrecordable blood pressure. Uterine clostridial infection was suspected clinically and she was referred for intensive care.

On examination she was apprehensive and shivering, with a rectal temperature of $100 \cdot 4^{\circ} \mathrm{F}$. $\left(38^{\circ} \mathrm{C}\right.$.). Blood pressure was $80 / 60$ $\mathrm{mm}$. $\mathrm{Hg}$ (Fig. 1); radial pulse was 120 beats/min., of small volume. Her extremities were warm and dry. Serum electrolytes were: sodium 136.5, potassium 3.6, and chloride $107 \mathrm{mEq} / 1$; blood urea was $152 \mathrm{mg}$. $/ 100 \mathrm{ml}$; total serum bilirubin $7.2 \mathrm{mg} . / 100 \mathrm{ml}$; serum calcium $10.4 \mathrm{mg} . / 100 \mathrm{ml}$; standard bicarbonate $26 \mathrm{mEq} / 1$; haemoglobin $11.6 \mathrm{~g} . / 100 \mathrm{ml}$.; packed cell volume $35 \%$; white cell count 22,450/cu. mm. Two blood cultures were negative. High cervical swabs grew a mixture of Escherichia coli and anaerobic streptococci.

She was observed carefully for 18 hours. Intravenous isoprenaline was used at this stage because, in spite of a raised central venous pressure $\left(170 \mathrm{~mm} . \mathrm{H}_{2} \mathrm{O}\right)$, blood pressure remained low with a small-volume radial pulse. The dose used was between 0.2 and $0.4 \mu \mathrm{g} . / \mathrm{min}$. The systolic pressure then increased to $120 \mathrm{~mm}$. Hg, but the diastolic remained low, giving a wide pulse pressure. Central venous pressure fell from 170 to $60 \mathrm{~mm}$. $\mathrm{H}_{2} \mathrm{O}$ over 16 hours. The patient had produced urine at an average of $48 \mathrm{ml}$./hour

Clinical Summary of 10 Cases Given Isoprenaline

\begin{tabular}{|c|c|c|c|c|c|c|c|c|c|c|c|}
\hline $\begin{array}{l}\text { Case } \\
\text { No. }\end{array}$ & Age & $\begin{array}{c}\text { Clinical } \\
\text { Diagnosis }\end{array}$ & Extremities & $\begin{array}{l}\text { Radial } \\
\text { Pulse } \\
\text { Volume }\end{array}$ & $\begin{array}{c}\text { B.P. } \\
\text { before } \\
\text { Isopre- } \\
\text { naline } \\
(\mathrm{mm} . \mathrm{Hg})\end{array}$ & $\begin{array}{c}\text { B.P. } \\
\text { after } \\
\text { Isopre- } \\
\text { naline } \\
(\mathrm{mm} . \mathrm{Hg})\end{array}$ & $\begin{array}{c}\text { C.V.P. } \\
\text { before } \\
\text { Isopre- } \\
\text { naline } \\
\left(\mathrm{mm} . \mathrm{H}_{2} \mathrm{O}\right)\end{array}$ & $\begin{array}{l}\text { C.V.P. } \\
\text { after } \\
\text { Isopre- } \\
\text { naline } \\
\left(\mathrm{mm} . \mathrm{H}_{2} \mathrm{O}\right)\end{array}$ & $\begin{array}{c}\text { Urine } \\
\text { Output } \\
\text { before } \\
\text { Isopre- } \\
\text { naline } \\
\text { (ml./hr.) }\end{array}$ & $\begin{array}{c}\text { Urine } \\
\text { Output } \\
\text { after } \\
\text { Isopre- } \\
\text { naline } \\
\text { (ml./hr.) }\end{array}$ & Mortality \\
\hline 1 & 23 & $\begin{array}{l}\text { Procured abortion, } \\
\text { ruptured uterus, } \\
\text { generalized peritonitis }\end{array}$ & $\begin{array}{l}\text { Warm } \\
\text { and dry }\end{array}$ & Small & $90 / 60$ & $130 / 75$ & 135 & 90 & 70 & 80 & Survived \\
\hline 2 & 34 & $\begin{array}{l}\text { Macerated fetus, } \\
\text { anaerobic uterine } \\
\text { infection }\end{array}$ & $\begin{array}{l}\text { Warm } \\
\text { and dry }\end{array}$ & Small & $80 / 60$ & $120 / 60$ & 170 & 60 & 48 & 70 & Survived \\
\hline 3 & 22 & $\begin{array}{l}\text { Procured abortion, } \\
\text { ruptured uterus, } \\
\text { generalized peritonitis }\end{array}$ & $\begin{array}{l}\text { Cold } \\
\text { and } \\
\text { clammy }\end{array}$ & Small & $90 / 70$ & $120 / 75$ & 220 & 140 & 60 & 65 & Died \\
\hline 4 & 34 & $\begin{array}{l}\text { Macerated fetus, } \\
\text { generalized peritonitis }\end{array}$ & $\begin{array}{l}\text { Cold } \\
\text { and } \\
\text { clammy }\end{array}$ & Small & $80 / 60$ & $130 / 70$ & 130 & 65 & 50 & 85 & $\begin{array}{c}\text { Survived } \\
\text { shock } \\
\text { episode }\end{array}$ \\
\hline 6 & 32 & $\begin{array}{l}\text { Ruptured abdominal } \\
\text { pregnancy at term, } \\
\text { purulent peritonitis }\end{array}$ & $\begin{array}{l}\text { Cold } \\
\text { and } \\
\text { clammy }\end{array}$ & $\begin{array}{l}\text { Impercep- } \\
\text { tible }\end{array}$ & $80 / 60$ & $115 / 80$ & 170 & 150 & 45 & 75 & Survived \\
\hline 7 & 47 & $\begin{array}{l}\text { Infected elephantoid } \\
\text { leg: renal failure }\end{array}$ & $\begin{array}{l}\text { Cold } \\
\text { and } \\
\text { clammy }\end{array}$ & Small & $55 / 30$ & $130 / 40$ & 180 & 150 & 15 & 10 & Died \\
\hline 8 & 60 & $\begin{array}{l}\text { Perforations of ileum, } \\
\text { faecal peritonitis }\end{array}$ & $\begin{array}{l}\text { Cold } \\
\text { and } \\
\text { clammy }\end{array}$ & $\begin{array}{l}\text { Impercep- } \\
\text { tible }\end{array}$ & $70 / 50$ & $140 / 70$ & 50 & 50 & 0 & 85 & $\begin{array}{l}\text { Survived } \\
\text { shock }\end{array}$ \\
\hline 9 & 50 & $\begin{array}{l}\text { Post-cholecystectomy } \\
\text { septicaemia }\end{array}$ & $\begin{array}{l}\text { Warm } \\
\text { and dry }\end{array}$ & Good & $70 / 40$ & $115 / 60$ & 210 & 180 & 15 & 140 & Died \\
\hline 10 & 50 & $\begin{array}{l}\text { Procured abortion, } \\
\text { pelvic peritonitis }\end{array}$ & $\begin{array}{l}\text { Warm } \\
\text { and dry }\end{array}$ & Small & $80 / 40$ & $110 / 40$ & 220 & 200 & 5 & 30 & Died \\
\hline 11 & 30 & $\begin{array}{l}\text { Gangrene of small } \\
\text { intestine due to } \\
\text { volvulus }\end{array}$ & $\begin{array}{l}\text { Cold } \\
\text { and } \\
\text { clammy }\end{array}$ & $\begin{array}{l}\text { Impercep- } \\
\text { tible }\end{array}$ & $\begin{array}{l}\text { Unrecord- } \\
\text { able }\end{array}$ & $100 / 50$ & 120 & 75 & 0 & 30 & $\begin{array}{c}\text { Survived } \\
\text { shock } \\
\text { episode }\end{array}$ \\
\hline
\end{tabular}




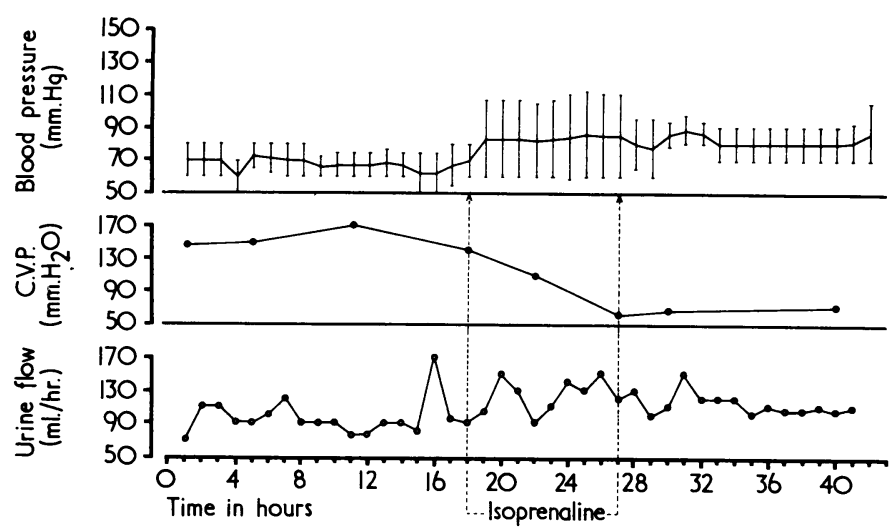

FIG. 1.-Case 2.

before isoprenaline was given, but this increased to $70 \mathrm{ml}$./hour during isoprenaline infusion. Isoprenaline was discontinued without subsequent difficulty. The patient survived, and 17 days later was discharged from hospital.

Comment.-Isoprenaline could have been witheld in this case (also Case 1), as it was in Cases 5 and 12, on the grounds that they had hypotension associated with small pulse volume but without oliguria. "Benign hypotension," however, is potentially dangerous, and the use of isoprenaline resulted in recovery from this state in both cas

\section{Case 6}

A 32-year-old woman was admitted with peritonitis at term. A straight $x$-ray film of the abdomen showed fetal parts lying transversely. Secondary abdominal pregnancy was diagnosed and preparations were made for urgent laparotomy. Preoperatively her temperature was $98^{\circ} \mathrm{F}$. $\left(36.7^{\circ} \mathrm{C}\right.$.), pulse rate 102 , and systolic blood pressure $120 \mathrm{~mm}$. Hg.

At laparotomy purulent peritonitis due to ruptured secondary abdominal pregnancy with placenta attached to broad ligament was found. A macerated fetus weighing $2 \frac{1}{2} \mathrm{lb}$. $(1.1 \mathrm{~kg}$.) was removed and a left salpingo-oophorectomy performed. After peritoneal toilet the abdomen was closed in layers with drainage. The patient received 2 pints $(1,140 \mathrm{ml}$.) of blood during the procedure and antibiotic therapy was begun. She collapsed suddenly 10 hours later with unrecordable blood pressure, imperceptible radial pulse, cold clammy extremities, and a clouded sensorium. At this stage she was moved to an intensive care unit.

Serum electrolyte levels were: sodium 119 , potassium $5 \cdot 0$, chloride $118 \mathrm{mEq} / \mathrm{l}$; blood urea was $32 \mathrm{mg} . / 100 \mathrm{ml}$.; total bilirubin $6.0 \mathrm{mg} . / 100 \mathrm{ml}$; standard bicarbonate $28 \mathrm{mEq} / 1$; haemoglobin $12.9 \mathrm{~g} . / 100 \mathrm{ml}$; white cell count $12,650 / \mathrm{cu} . \mathrm{mm}$.

The patient remained gravely ill over the next 12 hours, with a
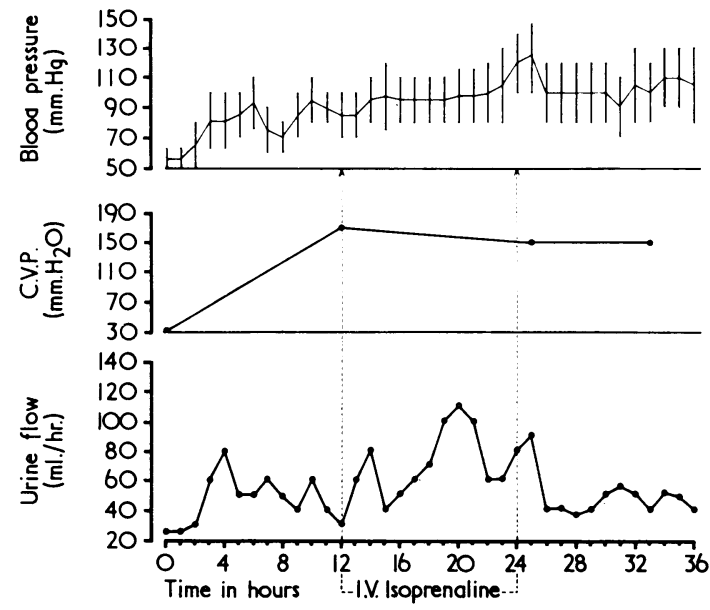

FIG. 2.-Case 6 labile blood pressure (Fig. 2), cutaneous vasoconstriction, and a clouded sensorium. Intravenous isoprenaline was used at this stage in an attempt to improve the "cold hypotension" which persisted in spite of a raised central venous pressure $\left(170 \mathrm{~mm} . \mathrm{H}_{2} \mathrm{O}\right)$. The dose used was between 0.4 and $0.6 \mu \mathrm{g} . / \mathrm{min}$. The response to isoprenaline was encouraging. Both systolic and diastolic pressures increased $(115 / 80 \mathrm{~mm}$. $\mathrm{Hg})$, but the central venous pressure did not alter significantly. Urine output of an average of $45 \mathrm{ml}$./hour before, increased to an average of $75 \mathrm{ml}$./hour during isoprenaline infusion. The patient survived the shock episode and was discharged from hospital, but not until six weeks later because of a subphrenic infection, pleural effusion, and smouldering peritonitis.

\section{Case 8}

A man aged 60 had an emergency laparotomy for faecal peritonitis resulting from two ileal perforations, which were sutured, and the peritoneum was drained. In spite of intravenous fluids and antibiotics he collapsed two days later and was referred for intensive care. On examination he was unconscious with cold clammy extremities, unrecordable blood pressure, and a radial pulse of 115 beats/min., regular, with a small volume. Rectal temperature was $100^{\circ} \mathrm{F}$. $\left(37.8^{\circ} \mathrm{C}\right.$.). He had not produced urine over the previous 11 hours.

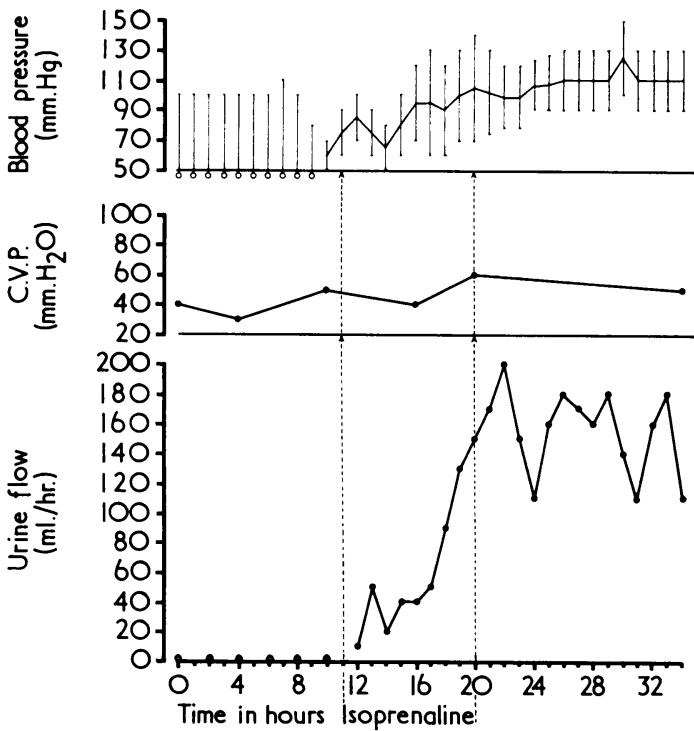

$$
\text { F:G. 3.-Case } 8
$$

Serum electrolyte levels were: sodium 140 , potassium 3.7 , and chloride $104 \mathrm{mEq} / 1$.; blood urea was $256 \mathrm{mg}$./100 ml.; total serum bilirubin $1.8 \mathrm{mg} . / 100 \mathrm{ml}$; standard bicarbonate $22 \mathrm{mEq} / \mathrm{l}$; haemoglobin 9.0 g. $/ 100 \mathrm{ml}$; packed cell volume $31 \%$; white cell count 50,050/cu. mm. Two blood cultures were negative.

Isoprenaline infusion was begun because the patient's condition was deteriorating visibly; the blood pressure was falling despite increasing the rate of intravenous fluids. A further drop in systolic pressure was anticipated because the central venous pressure was low. The dose of isoprenaline used was between 0.4 and 0.6 $\mu \mathrm{g} . / \mathrm{min}$. A drop in systolic pressure did occur after a transient rise, but it was matched by giving more intravenous fluids. Central venous pressure remained low throughout (Fig. 3). Urine output, which had been nil for 11 hours before isoprenaline was given, increased briskly. At the height of the diuresis $196 \mathrm{ml}$./hour was recorded. The blood urea was $256 \mathrm{mg}$. $/ 100 \mathrm{ml}$. at the beginning of treatment and it remained high at $280 \mathrm{mg} . / 100 \mathrm{ml}$. three days later, despite continuing diuresis. The patient survived the shock episode, but died a week later of bilateral lobar pneumonia.

\section{Discussion}

The rationale behind the use of isoprenaline in septic shock stems from three observations.

Firstly, heart failure due to a primary depressant effect of 
endotoxin on the myocardium occurs in some cases of septic shock (MacLean et al., 1965; McGowan and Walters, 1966; Anderson et al., 1967; Siegel and Fabian, 1967; Starzecki and Spink, 1968). This view, however, is not universally accepted (Vaughn et al., 1968). In practice, isoprenaline improves survival in experimental endotoxic shock (Halmagyi et al., 1963; Vick et al., 1965; Siegel and Fabian, 1967; Starzecki and Spink, 1968), and there are favourable reports of isoprenaline as an adjuvant in the management of septic shock in man (MacLean et al., 1965; Kardos, 1966; Du Toit et al., 1966; Baue, 1968). Vasodilator drugs are recommended for patients in shock who do not respond to adequate transfusion (Lancet, 1965). When "warm hypotension" persists in spite of a raised central venous pressure additional isoprenaline is probably not required, since the peripheral circulation is probably adequate and nothing more than lowering central venous pressure and increasing systolic pressure may be achieved.

Secondly, renal failure may complicate septic shock by the dual mechanism of direct and reflex vasoconstriction in the renal vascular tree, and isoprenaline abolishes both (Siegel and Fabian, 1967). In shock, kidney function occasionally remains satisfactory at systolic pressures below $80 \mathrm{~mm}$. $\mathrm{Hg}$ (McGowan and Walters, 1966; MacLean, 1966). Five patients in this series (Cases 1-4 and 6) had hypotension with smallvolume radial pulse but good urine output, while Cases 3, 4, and 6 also had cold and clammy extremities. Once the infection had been controlled, additional isoprenaline expedited the recovery of all except one patient (Case 3), who was too ill to tolerate drainage of pelvic abscess.

Thirdly, in the lungs, Halmagyi et al. (1965) showed that isoprenaline rapidly abolished both vasoconstriction and closure of alveolar ducts in sheep.

Massive pulmonary oedema is a recognized serious complicaton of septic shock (Frank, 1964; Kardos, 1966; Riordan and Walters, 1968). In the present series, of the five patients who died during the acute phase with pulmonary oedema, three also had acute renal failure. The association of pulmonary oedema and renal failure indicates a poor prognosis (Riordan and Walters, 1968). With the limited resources available for this study, isoprenaline did not appreciably alter the outlook for these patients.

In this study the following effects of intravenous isoprenaline were observed. Sinus tachycardia occurred immediately in all cases, with rates between 120 and 160 beats per minute. In one patient (Case 10) ventricular ectopic beats appeared, whereas in all cases the radial pulse became more readily palpable, of better volume, and collapsing in character, the extremities became warmer, pulsations were felt in digital vessels, and cold perspiration ceased. Six patients complained of palpitation, while in one patient (Case 7) an extensive desquamation of skin was observed. The effect on blood pressure was variable; the expected effect of a rise in systolic and fall in diastolic pressure occurred only infrequently. In general, the systolic pressure rose provided the central venous pressure was adequate $\left(>120 \mathrm{~mm} . \mathrm{H}_{2} \mathrm{O}\right)$ Central venous pressure, however, tended to fall during isoprenaline infusion. Though urinary output improved in all cases except two, it is noteworthy that a copious diuresis of about $100 \mathrm{ml}$./hour had the same grave prognostic significance as oliguria, since both indicated impaired renal function (Spink, 1962).

The above observations agree with the conclusion of MacLean (1966) that "in the absence of cardiac output determinations a favourable response to isoprenaline consists of increased heart rate, increase in arterial blood pressure, fall in central venous pressure, and increased urine output."

In 6 out of the 10 cases the dose of $0.2-0.6 \mu \mathrm{g} . / \mathrm{min}$. was satisfactory and the drug was discontinued without subsequent difficulty. In the remaining four cases, however, difficulties in weaning patients off isoprenaline and the need for progressively larger doses were associated with persistently high central venous pressure, massive pulmonary oedema, and impaired kidney function.

We are grateful to Professor S. R. A. Dodu for help and advice and to Messrs. Pharmax (U.K.) Ltd., Poviet Products, Amsterdam, and Glaxo-Allenbury (Ghana) Ltd., for donating isoprenaline, dextran, and cephaloridine respectively, and to all colleagues who referred patients.

Requests for reprints to Mr. J. L. Wosornu, Department of Surgery, Royal Postgraduate Medical School, Hammersmith Hospital, Ducane Road, London W.12.

\section{REFERENCES}

Anderson, R. W., James, P. M., Brendenberg, E., and Hardway, R. M. (1967). Annals of Surgery, 165, 341 .

Baue, A. E. (1968). Surgery Gynecology and Obstetrics, 127, 849.

Blair, E., Wise, A., and Mackay, A. G. (1969). fournal of the American Medical Association, 207, 333.

Campbell, D., Reid, J. M., Tefler, A. B. M., and Fitch, W. (1967). British Medical fournal, 4, 255.

Du Toit, H. J., et al. (1966) Lancet, 2, 143.

Frank, E. D. (1964). In Shock, edited by S. G. Hershey, p. 129.

Halmagyi, D. F. J., Horner, G. J., and Starzecki, B. (1965). Medical fournal of Australia, 2, 141.

Halmagyi, D. F. J., Starzecki, B., and Horner, G. J. (1963). Fournal of Applied Physiology, 18, 544.

Innes, I. R., and Nickerson, M. (1960). In The Pharmacological Basis of Therapeutics, edited by L. S. Goodman and A. Gilman, p. 533. New York, McMillan.

Kardos, G. G. (1966). New England fournal of Medicine, 274, 868. Lancet, 1965, 1, 255.

Lillehei, R. C., Longerbeam, J. K., Bloch, J. H., and Manax, W. G. (1964). Annals of Surgery, 160, 682.

McGowan, G. K., and Walters, G. (1966). Lancet, 1, 611.

MacLean, L. D. (1966). British fournal of Anaesthesia, 38, 255.

MacLean, L. D., Duff, J. H., Scott, H. M., and Peretz, D. I. (1965) Surgery, Gynecology and Obstetrics, 120, 1.

Nickerson, M. (1962). In Shock, Pathogenesis and Therapy: An International Symposium, edited by K. D. Bock, p. 356. New York Academic Press.

Riordan, J. F., and Walters, G. (1968). Lancet, 1, 719

Siegel, J. H., and Fabian, M. (1967). Fournal of the American Medical Association, 200, 696.

Spink, W. W. (1962). Annals of Internal Medicine, 57, 538.

Starzecki, B., and Spink, W. W. (1968). Fournal of Clinical Investigation, 47, 2193.

Vaughn, D. L., Gunter, C. A., and Stookey, J. L. (1968). Surgery, Gynecology and Obstetrics, 126, 1309.

Vick, J. A., Ciuchta, H. P., and Manthei, J. H. (1965). Fournal of Pharmacology and Experimental Therapeutics, 150, 382.

Walters, G., and McGowan, G. K. (1963). Lancet, 2, 17. 